\title{
Life history of Dulichiella appendiculata (Amphipoda, Senticaudata, Melitidae) in Maryland Coastal Bays, USA
}

\author{
Andrés Giovani Morales-Núñez*, Paulinus Chigbu \\ NSF-CREST Center for the Integrated Study of Coastal Ecosystem Processes and Dynamics in the Mid-Atlantic Region \\ (CISCEP), and NOAA Living Marine Resources Cooperative Science Center (LMRCSC), Department of Natural Sciences, \\ University of Maryland Eastern Shore, Princess Anne, MD 21853, USA
}

\begin{abstract}
Epibenthic samples collected from March to December 2012 (except September) in Maryland Coastal Bays (MCBs) were used to study the reproductive biology of Dulichiella appendiculata, an amphipod species common in estuaries of the Atlantic and Gulf coasts of the USA, whose life history is not well known. Mean densities $( \pm \mathrm{SE})$ of $D$. appendiculata increased from May to July, and declined thereafter. The species reproduced continuously from April (spring) to October (fall). The proportions of ovigerous to non-ovigerous females increased with temperature, from $\sim 70 \%$ (April), when mean water temperature was $14.7 \pm 0.77^{\circ} \mathrm{C}$, to $\sim 94 \%$ (July), when water temperature was at its peak $\left(26.4 \pm 0.23^{\circ} \mathrm{C}\right)$, before decreasing to $0 \%$ (November) when the temperature was $9.6 \pm 0.2^{\circ} \mathrm{C}$. The maximum body lengths of non-ovigerous $(9.75 \mathrm{~mm})$ and ovigerous $(9.85 \mathrm{~mm})$ females, and males $(11.1 \mathrm{~mm})$ were larger than values previously reported in a D. appendiculata population in Beaufort, North Carolina, USA. Large ovigerous females from an overwintering cohort produced juveniles in April, and then disappeared from the population by June, leaving behind small, less fecund ovigerous females belonging to a new generation to produce juveniles. Thus, ovigerous females were smaller in size in June (mean \pm SE: $4.8 \pm 0.2 \mathrm{~mm}$ ) than in April $(7.3 \pm 0.1 \mathrm{~mm})$ and May $(8.8 \pm 0.5 \mathrm{~mm})$. Males outnumbered females from May to October, but the reverse was the case in April $(\mathrm{p}<0.05)$. The $D$. appendiculata population in MCBs has a semi-annual, iteroparous life history, with a longevity of about 6 mo (spring breeder) and 9 mo (fall breeder).
\end{abstract}

KEY WORDS: Amphipoda · Dulichiella appendiculata · Life history · Maryland Coastal Bays · Mid-Atlantic region

\section{INTRODUCTION}

Dulichiella appendiculata (Say, 1818) is a very common species of amphipod distributed along the Atlantic and Gulf coasts of the United States from Delaware to Louisiana (Nelson 1980, LeCroy 2000, Lowry \& Springthorpe 2007). It is epibenthic and found in shallow waters, mainly near shores, grass beds, fouling communities, and among algae, sponges, ascidians, hydroids, and bryozoans (LeCroy 2000, Lowry \& Springthorpe 2007). In addition, it has

\footnotetext{
*Corresponding author: agmorales@umes.edu
}

been reported that $D$. appendiculata can consume some macroalgae (Duffy \& Hay 2000, Lowry \& Springthorpe 2007). Despite its wide distribution on the east coast of the United States, information is scarce on its reproductive biology.

Amphipods exhibit various life-history traits (Morino 1978, Nelson 1980, Van Dolah \& Bird 1980, Wildish 1982, Sainte-Marie 1991). Wildish (1982) classified the life history of gammarideans into 6 basic categories: (1) multivoltine (more than 1 generation per year) semiannual, (2) univoltine (1 generation per

(C) The authors 2016. Open Access under Creative Commons by Attribution Licence. Use, distribution and reproduction are unrestricted. Authors and original publication must be credited.

Publisher: Inter-Research · www.int-res.com 
year), (3) multivoltine annual, (4) semelparous (single-brooded) biannual, (5) semelparous perennial, and (6) iteroparous (multiple-brooded) perennial. Only a few publications exist on the reproductive biology of melitiid amphipods (Nelson 1980, Van Dolah \& Bird 1980, Sainte-Marie 1991), though the information they contain on $D$. appendiculata was based on data collected in North Carolina (Nelson 1978). Prior to this study, the only information available on the species in Maryland Coastal Bays (MCBs) is in grey literature (e.g. Llansó et al. 2002, 2004) and is limited to its occurrence and densities. Thus, the life history, reproductive biology, and population dynamics of $D$. appendiculata have received little attention. The present study aims to describe, for the first time, the life history and some aspects of the reproductive biology of $D$. appendiculata in MCBs.

\section{MATERIALS AND METHODS}

\section{Study area}

The Maryland Coastal Bays (MCBs) is a barrierisland system located on the eastern part of the Delmarva Peninsula, USA. The system consists of 5 principal lagoons distributed in 2 areas: Assawoman and Isle of Wight Bays, located in the northern area of the MCBs, and Sinepuxent, Newport, and Chincoteague Bays located in the southern area of the MCBs (Fig. 1). These 5 bays differ with regard to depth, flushing rate, surface area, and anthropogenic activity. In general, the MCBs are shallow with an average depth of $1.2 \mathrm{~m}$, predominantly polyhaline with salinity $>25$, and a surface area that ranges from $15.9 \mathrm{~km}^{2}$ in Newport Bay to $189 \mathrm{~km}^{2}$ in Chincoteague Bay (Chaillou et al. 1996, Wazniak et al. 2004).

\section{Sample collection and processing}

Samples were taken at 13 sites (8 sites in the southern area and 5 in the northern area) (Fig. 1). Sampling was conducted monthly for 9 mo from March to December 2012, although due to inclement weather conditions, samples were not collected in September. Samples were collected using an epibenthic sled $\left(\right.$ area $\left.=0.39 \mathrm{~m}^{2}\right)$, with a $1.0 \mathrm{~mm}$ mesh size net. A flow meter Model 2030R (General Oceanics) was attached to the net frame in order to determine the volume of water that passed through the net during each sampling event. Field sampling was completed in $2 \mathrm{~d}$ each month. At each site, 2 horizontal tows were con-

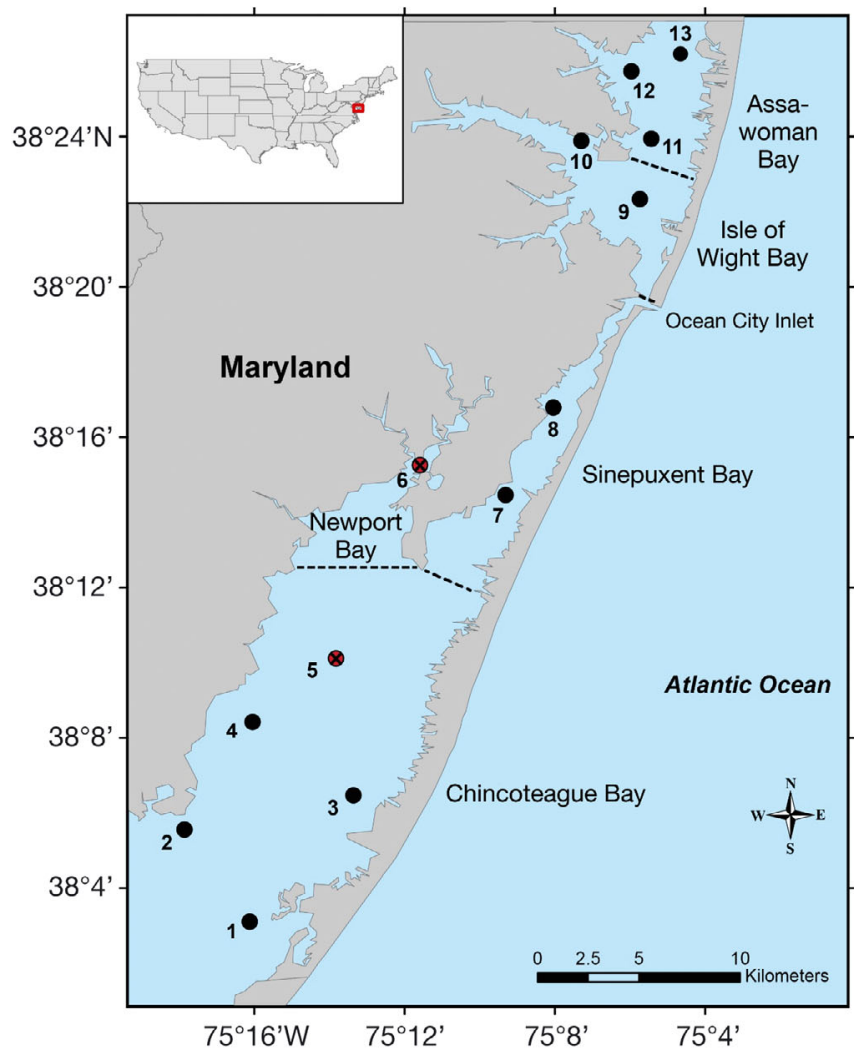

Fig. 1. Map of Maryland Coastal Bays (MCBs) indicating the 13 sites sampled. Black circles: the 11 sites where Dulichiella appendiculata were collected; dotted lines separate bays

ducted at an average speed of 2 knots for $5 \mathrm{~min}$. In the field, the net was rinsed and all macroinvertebrates were passed through a $0.5 \mathrm{~mm}$ sieve. Additionally, epifauna were separated from macroalgae by shaking each macroalgal fragment in a bucket filled with seawater. The macroinvertebrates retained were passed through a $0.5 \mathrm{~mm}$ sieve, and all the invertebrates were fixed in $5 \%$ neutral buffered formalin. All macroalgae collected with the sled were stored in plastic bags with seawater in a cooler. Subsequently, the wet weight of the macroalgae collected at each site was determined in the laboratory. The macroalgae were washed over a sieve with a $0.3 \mathrm{~mm}$ mesh size. Each macroalgal fragment was then visually examined further to confirm that all epifaunal invertebrates were removed. All amphipods collected were counted, identified to the lowest practical taxonomic level, and preserved in ethanol $(70 \%)$.

Water quality data were collected in situ using a YSI 6600 Multi-Parameter Water Quality Sonde and included water temperature, salinity, dissolved oxygen, and $\mathrm{pH}$, which were all recorded at $0.3 \mathrm{~m}$ from 
the bottom (Table 1). Additionally, water depth and clarity (i.e. Secchi disc transparency) were recorded at each site.

The densities of Dulichiella appendiculata were estimated and expressed as numbers of individuals per square meter (ind. $\mathrm{m}^{-2}$ ), and macroalgal abundance was expressed as grams wet weight (WW) per square meter $\left(\mathrm{g} W \mathrm{~W} \mathrm{~m}^{-2}\right)$. After all the specimens collected each month were counted, the size-structure of the amphipod species was determined each month using length measurements of 150 individuals (i.e. based on the lowest total abundance of specimens found in April 2012) from the samples, with the exception of November, when only a total of 9 individuals found in the samples were measured. Subsamples of the amphipods were taken from each site sampled, and individual amphipods were selected as encountered from each subsample until 150 individuals were measured. Additionally,
Table 1. Mean values of environmental parameters measured at 13 stations per month in Maryland Coastal Bays (MCBs) in 2012. Data are means \pm SE. - no data were collected

\begin{tabular}{|lccccc|}
\hline Month & $\begin{array}{c}\text { Temperature } \\
\left({ }^{\circ} \mathrm{C}\right)\end{array}$ & $\begin{array}{c}\text { Salinity } \\
(\mathrm{PSU})\end{array}$ & $\begin{array}{c}\text { Dissolved } \\
\text { oxygen } \\
\left(\mathrm{mg} \mathrm{l}^{-1}\right)\end{array}$ & $\mathrm{pH}$ & $\begin{array}{c}\text { Depth } \\
(\mathrm{m})\end{array}$ \\
\hline Mar & $11.8 \pm 0.60$ & $32.2 \pm 1.20$ & $9.1 \pm 0.19$ & $8.0 \pm 0.05$ & - \\
Apr & $14.7 \pm 0.77$ & $34.6 \pm 0.76$ & $7.9 \pm 0.10$ & $8.0 \pm 0.02$ & $1.9 \pm 0.13$ \\
May & $17.2 \pm 0.49$ & $34.1 \pm 0.53$ & $7.6 \pm 0.19$ & $8.0 \pm 0.02$ & $1.6 \pm 0.26$ \\
Jun & $21.7 \pm 0.34$ & $32.5 \pm 0.46$ & $6.9 \pm 0.13$ & $7.8 \pm 0.40$ & $1.9 \pm 0.14$ \\
Jul & $26.4 \pm 0.23$ & $32.9 \pm 0.45$ & $6.0 \pm 0.16$ & $7.8 \pm 0.03$ & $2.0 \pm 0.13$ \\
Aug & $24.5 \pm 0.11$ & $34.4 \pm 0.51$ & $5.7 \pm 0.24$ & $7.7 \pm 0.04$ & $1.7 \pm 0.21$ \\
Oct & $17.6 \pm 0.10$ & $27.6 \pm 0.60$ & $8.1 \pm 0.10$ & $8.0 \pm 0.0$ & $2.1 \pm 0.16$ \\
Nov & $9.6 \pm 0.20$ & $26.4 \pm 0.80$ & $10.4 \pm 0.30$ & $8.0 \pm 0.0$ & $2.2 \pm 0.26$ \\
Dec & $8.0 \pm 0.10$ & $28.2 \pm 0.60$ & $10.3 \pm 0.10$ & $8.0 \pm 0.0$ & $2.1 \pm 0.24$ \\
\hline
\end{tabular}

during each month, the selected specimens of $D$. appendiculata were sexed and classified into 4 categories: (1) juveniles (Fig. 2A) - specimens $<2.5 \mathrm{~mm}$ TL and without distinctive characteristics (e.g. absence of oostegites or asymmetrical second gnatho-

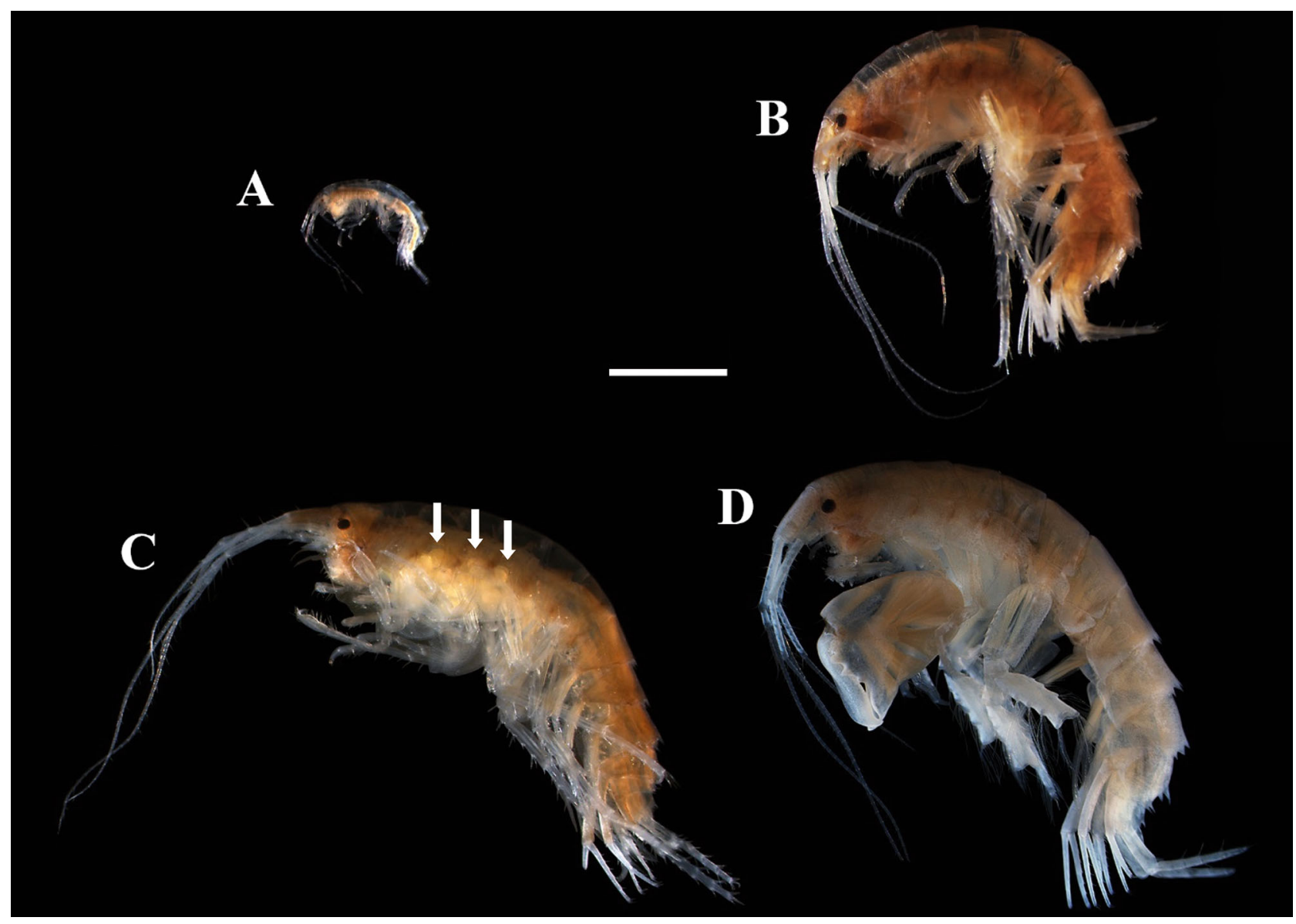

Fig. 2. Lateral view of habitus of Dulichiella appendiculata (A) juvenile, $2.43 \mathrm{~mm} \mathrm{TL}$ (B) non-ovigerous female, $9.0 \mathrm{~mm}$ TL; (C) ovigerous female, $8.90 \mathrm{~mm} \mathrm{TL}$ (D) male, $10.7 \mathrm{~mm}$ TL. Arrows indicate embryos; scale bar: $2.0 \mathrm{~mm}$ 
pod), (2) non-ovigerous females (Fig. 2B) - with presence of asetose oostegites, (3) ovigerous females (Fig. 2C) - with fully developed setose oostegites and carrying embryos in the marsupium, and (4) males (Fig. 2D) - with asymmetrical second gnathopod. Under a stereomicroscope, embryos were removed from undamaged marsupia of gravid females and counted. Total body length (TL) was measured from the posterior margin of the rostrum to the anterior margin of the telson. On the basis of TL, individuals were pooled into size classes using a size class interval of $1 \mathrm{~mm}$. All measurements were taken with the aid of an eye-piece micrometer $( \pm 0.1 \mathrm{~mm})$ under a stereomicroscope.

Spearman's rank correlation coefficients $\left(r_{s}\right)$ were calculated to assess the relationships between $D$. appendiculata abundance and macroalgal abundance, and the relationships of environmental factors (i.e. water temperature, salinity, dissolved oxygen [DO], and $\mathrm{pH}$ ) with the proportion of ovigerous female in the total population. A Chi-squared test was used to determine whether there were significant differences in the sex ratios, using the MINITAB statistical software package, Version 14.2.

\section{RESULTS}

\section{Abiotic variables}

The mean $( \pm \mathrm{SE})$ values of environmental parameters measured in the MCBs during this study period are summarized in Table 1 . Mean temperature $\left({ }^{\circ} \mathrm{C}\right)$ ranged from $8.0 \pm 0.1$ to $26.4 \pm 0.23$, salinity from 26.4 \pm 0.8 to $34.6 \pm 0.76$, and dissolved oxygen $\left(\mathrm{mg} \mathrm{l}^{-1}\right)$ from $6.0 \pm 0.16$ to $10.4 \pm 0.3$. Furthermore, $\mathrm{pH}$ ranged from $5.7 \pm 0.4$ to $8.0 \pm 0.05$, depth $(\mathrm{m})$ from $1.7 \pm 0.21$ to $2.2 \pm 0.26$, and Secchi depth $(\mathrm{m})$ transparency from $0.6 \pm 0.04$ to $1.2 \pm 0.06$.

\section{Variations in abundance of Dulichiella appendiculata}

A total of 16238 individuals of $D$. appendiculata were counted; of these, 909 were measured and sexed. Specimens of $D$. appendiculata were only found at 11 of the 13 sites sampled in the MCBs (Fig. 1). There was a positive correlation between the monthly mean abundance of $D$. appendiculata and macroalgae $\left(\mathrm{r}_{\mathrm{s}}=0.76, \mathrm{p}<0.003, \mathrm{n}=9\right)$ (Fig. 3A). Mean densities of $D$. appendiculata varied between months, ranging from $7.8 \pm 7.7$ to $0.0 \pm 0.0$ ind. $\mathrm{m}^{-2}$
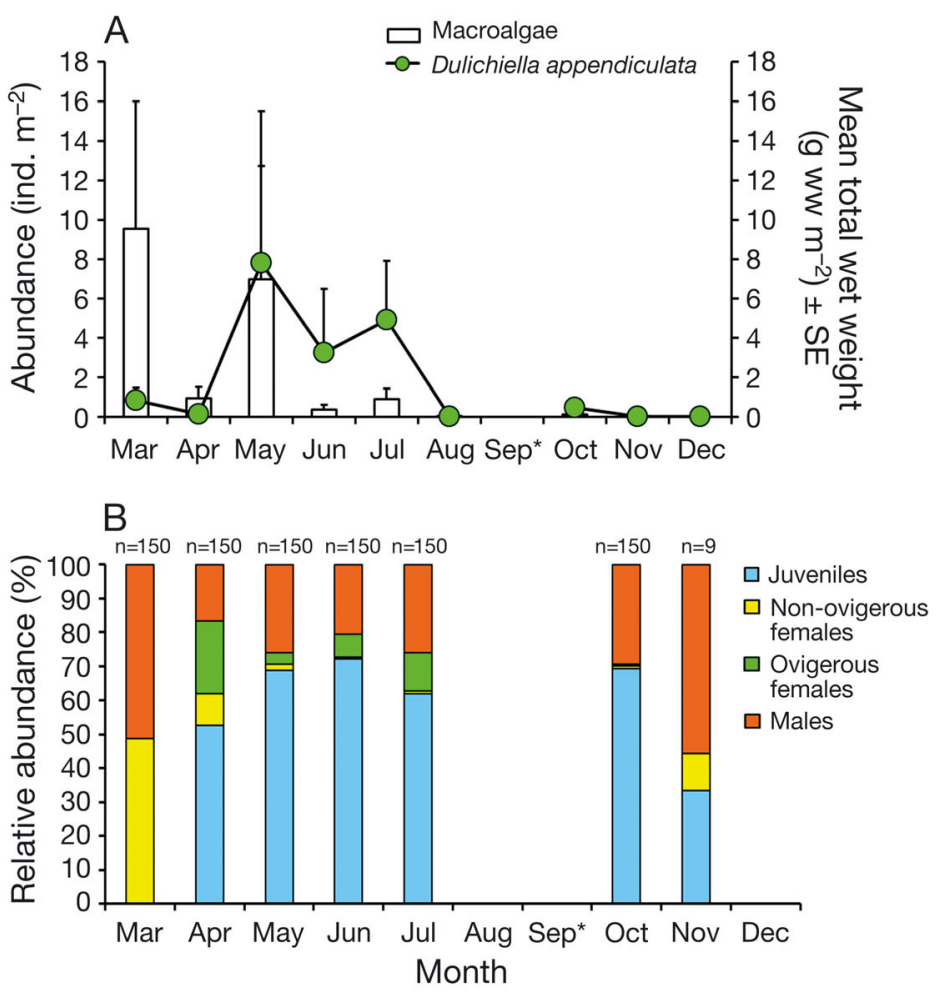

Fig. 3. Temporal patterns in (A) population density (mean \pm SE total abundance) of Dulichiella appendiculata and macroalgal biomass and (B) relative abundance of developmental stages of $D$. appendiculata. Sampling was conducted in August and December; no amphipods were collected.

${ }^{*}$ Samples were not taken in September

(Fig. 3A). Lowest mean total densities were found at the beginning of the study (March-April), but an increase was noticed from May $(7.8 \pm 7.7)$ to July $(4.9 \pm 3.0)$, followed by a decrease from August to December (Fig. 3A). In August and December, no specimens of $D$. appendiculata were found in the samples.

\section{Life history of Dulichiella appendiculata}

In April, juveniles of D. appendiculata first appeared in the samples and represented $>50 \%$ of the population $;$ by July, their proportion had exceeded $70 \%$ (Fig. 3B). The smallest juvenile measured $0.86 \mathrm{~mm}$ TL. Juveniles were most abundant in spring, with a decrease in summer through fall (Fig. 2B, Fig. S2A in the Supplement at www.int-res.com/articles/ suppl/b025p075_supp.pdf). The maximum TL of nonovigerous females, ovigerous females and males were $9.75,9.85$, and $11.1 \mathrm{~mm}$, respectively. Nonovigerous females were found from March to November (Fig. 2B, Fig. S1 in the Supplement at 


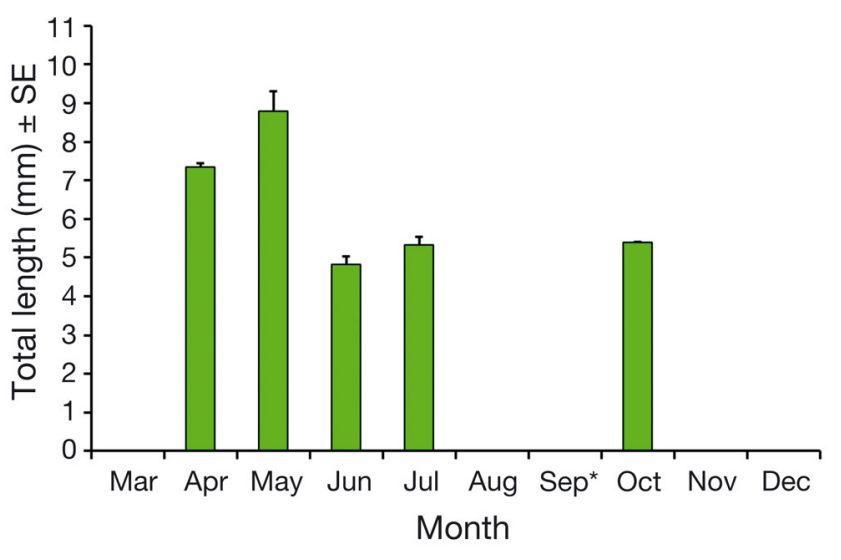

Fig. 4. Mean $( \pm \mathrm{SE}) \mathrm{TL}$ of ovigerous females of Dulichiella appendiculata collected from MCBs in 2012. Sampling was conducted in August and December; no amphipods were collected. *Samples were not taken in September

$\square$ Juveniles $\square$ Non-ovigerous females $\square$ Ovigerous females
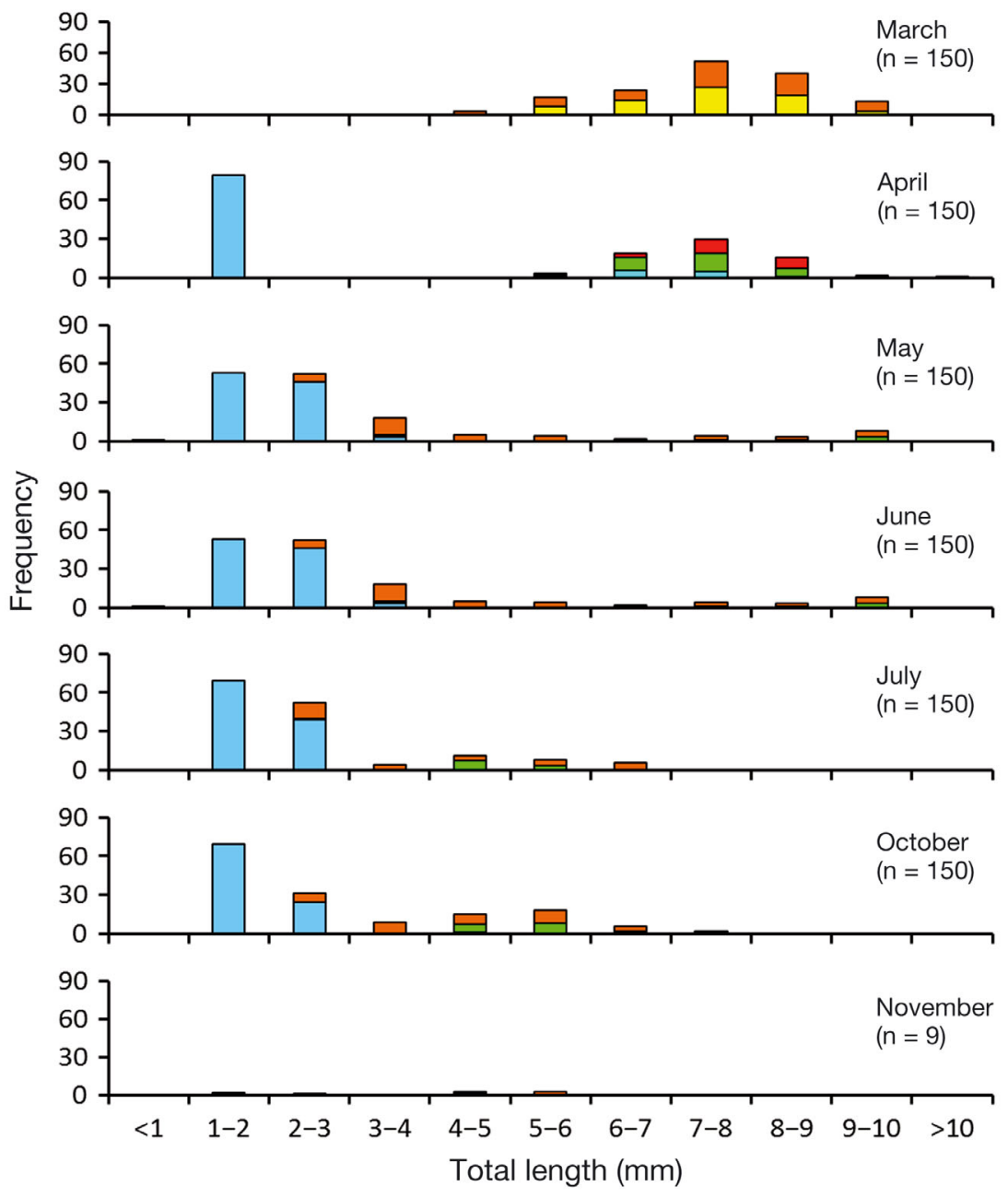

Fig. 5. Size-frequency distribution of Dulichiella appendiculata in MCBs from March to December (2012). D. appendiculata was not found in samples during August and December; no ovigerous females were found in November www.int-res.com/articles/suppl/b025p075_supp.pdf). The proportions of ovigerous relative to nonigerous females are presented in Fig. S1 in the Supplement. Ovigerous females increased in proportions from about $60 \%$ in spring (May) to about $94 \%$ August and December.

Mean $( \pm \mathrm{SE})$ sizes of ovigerous females (Fig. 4) gerous females of $D$. appendiculata from an overwintering cohort began to produce juveniles in April, and by June had disappeared from the cohort, leaving smaller ovigerous females belonging to a different generation to produce juveniles (Fig. 5). Hence, reproduction in the species was continuous from April to October (Figs. 2-4, Fig. S1 in the Supplement).

Overall, there was no significant correlation between the proportions of ovigerous females and any of the environmental variables (i.e. water temperature: $\mathrm{n}=12, \mathrm{r}_{\mathrm{s}}=-0.23, \mathrm{p}>0.503$; salinity: $\mathrm{n}=12, \mathrm{r}_{\mathrm{s}}=-0.09, \mathrm{p}>0.503$; dissolved oxygen: $\mathrm{n}=12, \mathrm{r}_{\mathrm{s}}=0.32, \mathrm{p}>$ 0.503; and $\mathrm{pH}: \mathrm{n}=12, \mathrm{r}_{\mathrm{s}}=0.14, \mathrm{p}>$ 0.503). However, the proportions of ovigerous to non-ovigerous females increased with temperature-from $\sim 70 \%$ (April) when mean water temperature was $14.7 \pm 0.77^{\circ} \mathrm{C}$ (Table 1) to $\sim 94 \%$ (July) when water temperature was at its peak $\left(26.4 \pm 0.23^{\circ} \mathrm{C}\right)$, before decreasing to $0 \%$ (November) when the temperature was $9.6 \pm 0.2^{\circ} \mathrm{C}$ (Table 1). Males were present in all months during which $D$. appendiculata were captured, but their proportions were lowest in early spring (April) (Fig. 3). Generally, males were more abundant than ovigerous females from spring to fall (Fig. S2A in the Supplement), but males were smaller in size than ovigerous females (Fig. S2B). Additionally, the mean sizes of females (ovigerous and nonovigerous) and males were smaller in summer and fall than in winter and spring (Fig. S2B). 


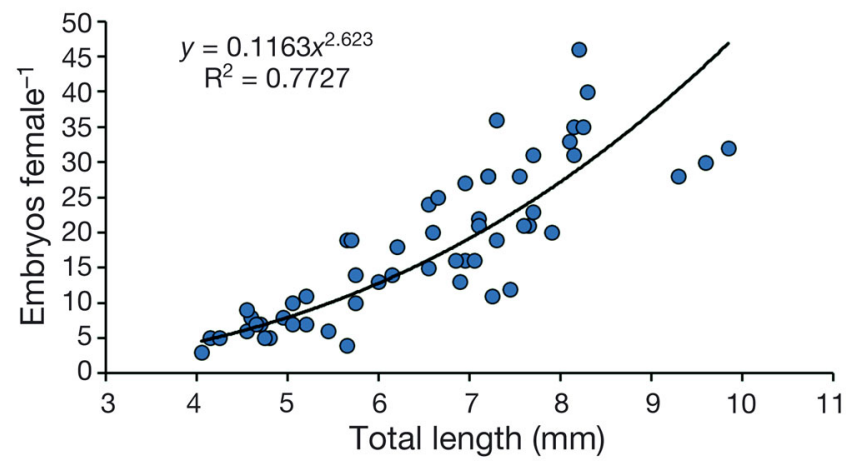

Fig. 6. Relationship between the number of embryos per female and TL (mm) of ovigerous females of Dulichiella appendiculata in MCBs

The mean size of gravid females was $6.5 \pm 0.2 \mathrm{~mm}$ ( $\mathrm{n}=65)$; the highest number of embryos per female was observed during spring (peak in April) and summer (peak in July), whereas the lowest numbers were recorded in fall. The smallest observed ovigerous female was $4.1 \mathrm{~mm}$, while the largest was $9.9 \mathrm{~mm}$. The average number of embryos per female was 18.3 \pm 1.4 , ranging from 3 to 46 . The mean diameter of embryos was $0.36 \mathrm{~mm}$, ranging from 0.21 to $0.54 \mathrm{~mm}$. The number of embryos per ovigerous female increased significantly $\left(\mathrm{r}^{2}=0.77, \mathrm{p}<0.05\right)$ with TL (Fig. 6).

The ratio of males to females in the $D$. appendiculata population in the MCBs varied during the study period such that the number of males was significantly higher than females from May to October (Chi-squared $=11.57, \mathrm{df}=1, \mathrm{p}<0.05)$, but lower in April (Chi-squared $=4.18$, df $=1, \mathrm{p}<0.05$ ). However, the sex ratio was 1:1 in March, and sample size $(\mathrm{n}=9)$ was not adequate for assessing the sex ratio in November. In general, the temporal pattern of males to non-ovigerous females or ovigerous females was similar to that of male to total female ratios (Fig. S3A,B in the Supplement at www.int-res.com/ articles/suppl/b025p075_supp.pdf).

\section{DISCUSSION}

Dulichiella appendiculata in MCBs reproduces continuously from spring to fall, with embryo incubation and release of juveniles from the brood pouch occurring from April (early spring) through October (early fall). The presence of juveniles in our samples from April to November suggests that the spring and summer generations mature within a relatively short time period, have an incubation period of at least $1 \mathrm{mo}$, and reproduce more than once. This reproductive strategy concurs with the life-history type reported in low latitudes for amphipod species characterized as having small body size, short maturity time, and high reproductive potentials (Sainte-Marie 1991, Cunha et al. 2000, Aravind et al. 2007).

Steele \& Steele (1986) and Bacela \& Konopacka (2005) suggested that many northern iteroparous invertebrates overwinter as relatively large nonbreeding adults that produce a brood of young in the spring; then they die, and their offspring breed continuously at smaller sizes during the summer period. This is similar to our observation for $D$. appendiculata in MCBs. The overwintering (March) females were relatively large in size and by April/ May (mid/spring) had begun to be ovigerous. Thereafter, by June (late spring), a significant number of cohort members had disappeared from the population, and they were replaced by ovigerous females belonging to a new generation that reproduced at a relatively small body size. However, the small ovigerous females found in summer in this study were $71 \%$ larger in size than small ovigerous females reported by Nelson (1980) in Beaufort North Carolina, USA (Table 2).

In MCBs, the breeding season (with the highest proportions of ovigerous females) of $D$. appendiculata was in spring, beginning in April when the water temperature was above $6.4^{\circ} \mathrm{C}$; the abundance of amphipods also increased during the same season (A. G. Morales-Núñez unpubl. data). Cunha et al.

Table 2. A comparison of life-history traits of Dulichiella appendiculata in MCBs (present study) with a population from Beaufort, North Carolina, USA. TL: total length

\begin{tabular}{|c|c|c|c|c|c|c|}
\hline \multirow{2}{*}{$\begin{array}{l}\text { Study locality } \\
\text { (latitude, longitude) }\end{array}$} & \multirow{2}{*}{$\begin{array}{c}\text { Period of } \\
\text { highest } \\
\text { abundance }\end{array}$} & \multicolumn{2}{|c|}{ - Reproductive females- } & \multirow{2}{*}{$\begin{array}{l}\text { Mean } \\
\text { brood size }\end{array}$} & \multirow{2}{*}{$\begin{array}{c}\text { Mean } \\
\text { embryo size } \\
(\mathrm{mm})\end{array}$} & \multirow[t]{2}{*}{ Source } \\
\hline & & $\begin{array}{l}\text { Min. TL } \\
(\mathrm{mm})\end{array}$ & $\begin{array}{l}\text { Mean TL } \\
(\mathrm{mm})\end{array}$ & & & \\
\hline $\begin{array}{l}\text { Beaufort } \\
\left(34^{\circ} 42^{\prime} 18.4^{\prime \prime} \mathrm{N}, 76^{\circ} 39^{\prime} 38.7^{\prime \prime} \mathrm{W}\right)\end{array}$ & Sep-Mar & 2.9 & $3.8^{\mathrm{a}}$ & $5.1^{\mathrm{a}}$ & $0.36^{\mathrm{a}}$ & Nelson (1980) \\
\hline $\begin{array}{l}\text { MCBs } \\
\left(38^{\circ} 12^{\prime} 55.3^{\prime \prime} \mathrm{N}, 75^{\circ} 10^{\prime} 50.1^{\prime \prime} \mathrm{W}\right)\end{array}$ & May-Jul & 4.1 & $\begin{array}{c}6.5 \pm 0.20 \\
(4.1-9.9)\end{array}$ & $\begin{array}{c}18.3 \pm 1.4 \\
(3-46)\end{array}$ & $\begin{array}{l}0.36 \pm 0.01 \\
(0.21-0.54)\end{array}$ & $\begin{array}{c}\text { Present study } \\
\quad(2012)\end{array}$ \\
\hline
\end{tabular}


(2000) estimated that, under the favorable temperature conditions that occur in late spring and summer, it could take females of the amphipod species Corophium multisetosum 1 mo to reach reproductive size. This reproductive strategy may be in response to constraints imposed mainly by low winter temperatures that are suboptimal for reproduction (Cunha et al. 2000).

The population density of $D$. appendiculata in our study was higher from May (mid-spring) to July (early summer) and lower from August (mid-summer) to December (late fall). The occurrence of a very low density or the virtual absence of specimens of the species at Sites 5 and 6 and during late summer and fall may be due to a lack of macroalgae in the samples. A positive correlation was observed between the abundance of $D$. appendiculata and macroalgae, particularly Agardhiella sp. and Gracilaria sp. in MCBs. Other factors such as algal cover, shelter, or inter-specific relationships have been reported to influence the distribution and abundance of amphipods in estuaries (Nicolaidou \& Karakiri 1989, Aravind et al. 2007). Macroalgae have been considered as the most important factor contributing to habitat structural complexity and heterogeneity in estuaries, coastal lagoons, and shallow waters (Vázquez-Luis et al. 2012), and are known to function, not only as food and nurseries, but also as shelter from predation (Poore 1994, Attrill et al. 2000).

Nelson's $(1978,1980)$ work on amphipods associated with eelgrass Zostera marina in Beaufort, North Carolina, contains the only published information on some aspects of the life history of $D$. appendiculata, although some of our results (Table 2) differ from his. For example, the mean TL of reproductive females (3.8 mm) and mean brood size (5.1) in the North Carolina population are smaller than the mean TL of reproductive females $(6.5 \mathrm{~mm})$ and mean brood size (18.3) of the MCBs D. appendiculata population (Table 2). These differences may be due to intraspecific phenotypic plasticity and life-history variation between the 2 populations driven by prevailing environmental factors, and appear to follow the metabolic theory 'hotter is smaller' proposed by Kingsolver \& Huey (2008). Additionally, Nelson (1978, 1980) reported that the highest abundance of $D$. appendiculata occurred from September to March and the lowest abundance during summer (Table 2). Conversely, in this study, the highest abundance of $D$. appendiculata was noted from May to July and the lowest abundance was found in mid-summer and fall (Table 2). It has been suggested that the steep decline in the abundance of amphipods in temperate shallow waters, during summer and fall, is due to high predation pressure (Nelson 1980, Cunha et al. 2000, Yu \& Suh 2006). In MCBs, the abundance of fish species increases beginning in spring (April) and peaks in June or July as juveniles of estuarinedependent fishes enter lagoons (S. Doctor, Maryland Department of Natural Resources, unpubl. data). The fishes begin to leave the lagoons as the temperature decreases in early fall (October), and, by November, the majority have moved into coastal waters. Since amphipods comprise a significant component of the diet of juvenile fishes in MCBs (Mayor 2015), predation by fishes likely contributes to the decline in $D$. appendiculata abundance from May to August in this study.

The mean embryo size reported in our study is similar to that reported by Nelson $(1978,1980)$ in a population of $D$. appendiculata in North Carolina (Table 2), despite the fact that the 2 populations differ with regard to the minimum size of reproductive females, mean size of reproductive females, and mean brood size (Table 2). It has previously been observed in amphipod populations that environmental factors (especially temperature, food availability, and predation) influence the mean size of reproductive females, brood size, and development of embryos (Nelson 1980, Yu \& Suh 2006).

In summary, the $D$. appendiculata population in MCBs has a semi-annual, iteroparous life history, with a longevity of about 6 mo (spring breeder) and 9 mo (fall breeder). The early generation of the population was produced by overwintering females in early to mid-spring, and the second generation in June-July was produced by females belonging to a different cohort in late spring and early summer that was born in May (mid-spring). Overwintering females that reproduced in spring were larger and more fecund than those that reproduced in summer, and their reproductive activity coincided with an increase in temperature beginning in April.

Acknowledgements. This research was supported by NSF CREST-CISCEP (Center of Research Excellence in Science and Technology Center for the Integrated Study of Coastal Ecosystem Processes and Dynamics in the Mid-Atlantic Region) Grant No. 1036586 and the NOAA LMRCSC (Living Marine Resources Cooperative Science Center) Grant No. NA11SEC4810002. We thank Captain Christopher Daniels for his assistance in collecting the samples, as well as Wilmelie Cruz-Marrero for help in drafting the study map. We are also grateful to Alexis Jackson who assisted with laboratory processing of the benthic invertebrate samples. We also thank the anonymous reviewers for their constructive and thoughtful comments, which have improved the quality of the paper. 


\section{LITERATURE CITED}

Aravind NP, Sheeba P, Nair KKC, Achutankutty CT (2007) Life history and population dynamics of an estuarine amphipod, Eriopisa chilkensis Chilton (Gammaridae). Estuar Coast Shelf Sci 74:87-95

Attrill MJ, Strong JA, Rowden AA (2000) Are macroinvertebrate communities influenced by seagrass structural complexity? Ecography 23:114-121

Bacela K, Konopacka A (2005) The life history of Pontogammarus robustoides, an alien amphipod species in Polish waters. J Crustac Biol 25:190-195

Chaillou JC, Weisberg SB, Kutz FW, DeMoss TE and others (1996) Assessment of the ecological condition of the Delaware \& Maryland Coastal Bays. EPA/620/R-96/004, U.S. Environmental Protection Agency, Office of Research \& Development, Washington, DC

Cunha MR, Sorbe JC, Moreira MH (2000) The amphipod Corophium multisetosum (Corophiidae) in Ria de Aveiro (NW Portugal). I. Life history and aspects of reproductive biology. Mar Biol 137:637-650

Duffy JE, Hay ME (2000) Strong impacts of grazing amphipods on the organization of a benthic community. Ecol Monogr 70:237-263

Kingsolver JG, Huey RB (2008) Size, temperature, and fitness: three rules. Evol Ecol Res 10:251-268

LeCroy SE (2000) An illustrated identification guide to the nearshore marine and estuarine gammaridean Amphipoda of Florida, Vol 1. Families Gammaridae, Hadziidae, Isaeidae, Melitidae and Oedicerotidae. Annual Report, Florida Department of Environmental Protection, Tallahassee, FL

Llansó RJ, Scott LC, Kelley FS (2002) National coastal assessment 2001 benthic community condition in Maryland's coastal bays. Maryland Department of Natural Resources Tidewater Ecosystem Assessment Division, Annapolis, MD

Llansó RJ, Scott LC, Kelley FS (2004) National coastal assessment 2001 benthic community condition in Maryland's coastal bays. Maryland Department of Natural Resources Tidewater Ecosystem Assessment Division, Annapolis, MD

Lowry JK, Springthorpe RT (2007) A revision of the tropical/temperate amphipod genus Dulichiella Stout, 1912, and the description of a new Atlantic genus Verdeia gen. nov. (Crustacea: Amphipoda: Melitidae). Zootaxa 1424: $1-62$

Editorial responsibility: Judith Grassle, New Brunswick, New Jersey, USA
Mayor E (2015) Population dynamics of mysids and their role in the trophic ecology of fishes in the Maryland Coastal Bays. PhD dissertation, University of Maryland Eastern Shore, Princess Anne, MD

Morino H (1978) Studies on the Talitridae (Amphipoda, Crustacea) in Japan. III. Life history and breeding activity of Orchestia platensis Krøyer. Publ Seto Mar Biol Lab 24:245-267

Nelson WG (1978) The community ecology of seagrass amphipods: predation and community structure, life histories and biogeography. PhD dissertation, Duke University, Durham, NC

Nelson WG (1980) Reproductive patterns of gammaridean amphipods. Sarsia 65:61-71

Nicolaidou A, Karakiri M (1989) The distribution of Amphipoda in a brackish-water lagoon in Greece. Mar Ecol (Berl) 10:131-139

Poore AGB (1994) Selective herbivory by amphipods inhabiting the brown alga Zonaria angustata. Mar Ecol Prog Ser 107:113-123

Sainte-Marie B (1991) A review of the reproductive bionomics of aquatic gammaridean amphipods: variation of life history traits with latitude, depth, salinity and super family. Hydrobiologia 223:189-227

Say $T$ (1818) An account of the Crustacea of the United States. J Acad Nat Sci Phila 1:374-401

Steele DH, Steele VJ (1986) The cost of reproduction in the amphipod Gammarus lawrencianus Bousfield, 1956. Crustaceana 51:176-182

Van Dolah RF, Bird E (1980) A comparison of reproductive patterns in epifaunal and infaunal gammaridean amphipods. Estuar Coast Mar Sci 11:593-604

Vázquez-Luis M, Borg JA, Sanchez-Jerez P, Bayle-Sempere JT (2012) Habitat colonization by amphipods: comparison between native and alien algae. J Exp Mar Biol Ecol 432-433:162-170

Wazniak C, Wells D, Hall M (2004) Maryland's Coastal Bays: ecosystem health assessment, Chapter 1.2. In: Wazniak C, Goshorn D, Matthew H, Blazer D and others (eds) The Maryland Coastal Bays ecosystem. Document Number DNR-12-1202-0009, Maryland Department of Natural Resources, Annapolis, MD, p 9-20

Wildish DJ (1982) Evolutionary ecology of reproduction in gammaridean Amphipoda. Int J Invertebr Reprod 5:1-19

$\mathrm{Yu} \mathrm{OH}$, Suh HL (2006) Life history and reproduction of the amphipod Synchelidium trioostegitum (Crustacea, Oedicerotidae) on a sandy shore in Korea. Mar Biol 150:141-148

Submitted: December 21, 2015; Accepted: June 9, 2016

Proofs received from author(s): August 4, 2016 